\title{
Ludwik Fleck: a message to start a new discourse
}

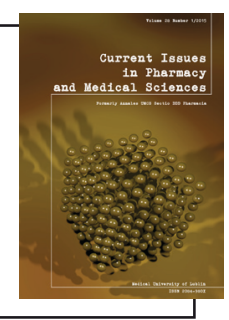

\author{
EWA Solska
}

Department of the Methodology of History, Institute of History, Maria Curie-Skłodowska University in Lublin, Poland

\begin{tabular}{|c|c|}
\hline ARTICLE INFO & ABSTRACT \\
\hline $\begin{array}{l}\text { Received } 16 \text { March } 2015 \\
\text { Accepted } 26 \text { March } 2015\end{array}$ & \multirow{2}{*}{$\begin{array}{l}\text { The goal of the present article is to initiate a series of papers on Ludwik Fleck's theories of } \\
\text { medical cognition and their contribution to contemporary research on science. I would } \\
\text { like, however, to begin with the last statement, in which he signaled, almost half a century } \\
\text { ahead of time, the current issues concerning scientific discourse in the socio-cultural } \\
\text { dimension. }\end{array}$} \\
\hline $\begin{array}{l}\text { Keywords: } \\
\text { Ludwik Fleck, } \\
\text { theory of science, } \\
\text { sociology of knowledge, } \\
\text { thought styles, } \\
\text { human dimension. }\end{array}$ & \\
\hline
\end{tabular}

\section{INTRODUCTION}

This year marks the $70^{\text {th }}$ anniversary of Ludwik Fleck's invitation to become Head of the Department of Medical Microbiology at the then UMCS [Maria Curie-Skłodowska University] Medical Faculty. Ludwik Fleck is a scholar who is well-known in the world as a philosopher of science and a pioneer of the sociology of knowledge. From the standpoint of history of medicine, it is impossible to disregard the importance of his work as a physician and microbiologist. As a graduate of medical studies at Jan Kazimierz University in Lvov (1919), he started work at Rudolf Weigl's laboratory in Przemyśl, and after returning to Lvov, he became his assistant. He worked at the General Hospital and the Social Insurance Institution, and in the 1930s, he established his own bacteriological laboratory. After the Soviets captured Lvov in September 1939, he became Associate Professor at the Ukrainian Medical Institute and director of Lvov's sanitary and bacteriological laboratory. From his Lvov period on (1921-1941), he conducted research on the methods of early diagnosis of typhus fever, on the method of distinguishing actual serum reactions, on bacteria variability and the concept of species in bacteriology, and on the category of infection and infectious disease. He introduced the term leukergy into the medical vocabulary while continuing his research, begun before WW2, on leukocyte defense reactions. During the war, while interned within the Lvov Ghetto and in the Auschwitz and Buchenwald concentration camps, he produced a typhus vaccine from the urine of the infected prisoners, and at the same time, despite the tragic circumstances, he conceptualized his observations of

\footnotetext{
* Corresponding author

e-mail: ewa.solska@poczta.umcs.lublin.pl
}

the circle of his associates, which would be the foundation for developing the sociological aspect of a new theory of science, which he continued to carry on during the whole of his time in Lublin (1945-52) [1].

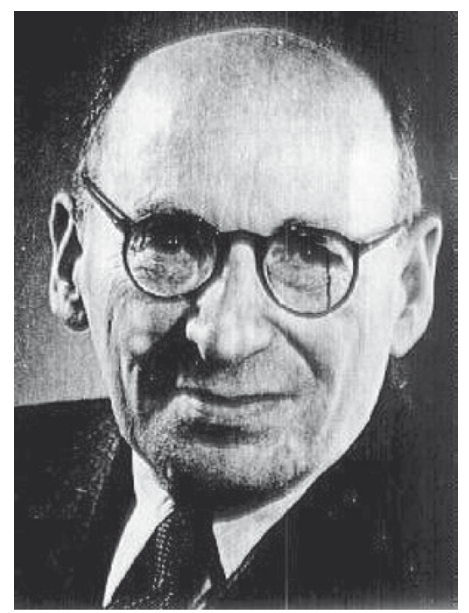

Photo 1. Ludwik Fleck

Fleck, in his opus magnum, The genesis and development of a scientific fact formulated the Introduction to the theory of thought style and thought collective [2]. Therein, he insisted that in natural history, like in art, only what is true to nature is true to culture [3]. In this statement, he summarizes the multiple links of scientific discourse, and formulates from this starting point, the fundamentals of the program of sociology of knowledge, by providing an outline of the methodological basis for the new trend in research on science. Of note, in this work, he presents the history of medicine as the exemplification of the thesis; and what he 
establishes in the sociological aspect, he applies to specialist practice. Two articles therein, in providing a discussion of the assumptions of the program, can be called its recapitulation in the context of the science of science and the question of the crisis in science [4]. Apart from the ethical postulate, they advance the possibility of seeing the comparative sociology of cognition as being a model of the science of thought styles. We are speaking here about the methodological postulate of interdisciplinarity, which would appear in research practice several decades later, and which enabled the rise of such orientations as life sciences, cybernetics and Science and Technology Studies (STS).

From the perspective of the last orientation, we should at once pose the following question: As economics, sociology, anthropology, cognitive science, scientometrics are all recognized as being disciplines that could be called the etiology of science - what is their significance to natural science studies? Furthermore, what has philosophy and semiotics (which says that metaphors can be used as scientific facts) got to do with medicine? Or, does that dominance of a paradigm truly assume that one of the views gains the status of being an absolute truth? The sociology of knowledge, in challenging the scientistic view about the privileged position of natural science, emphasizes its political or economic involvements. At the same time, the notions encompassed inside philosophy come into play, suggesting that such principles of modern consciousness as scientific methodology are, in reality, critically deconstructed and transformed, as were their premodern correlates. However, what is the purpose of such revelations? Did these come about just to disenchant science on the wave of postmodernist turns? Or, as Fleck suggests, considering the thesis of crisis in Science, did such happenstance make science more human [4]? But what does this last mean? Are we talking about general procedures, or about a hardly effective debate on the ethical dimensions of lab practices involving animal as test subjects? Will such a debate bring about change in the situation in which the results of scientific research are absorbed by military application? In our world, the world of biological and chemical weapons, the weapons of mass destructions, this situation appears to be socially adopted as one with no alternative.

In this context, Fleck focuses on the situation of the community of scientists. Having first-hand knowledge of these matters, he raises the problem of opportunism, corruption, mechanisms of eliminating dissenting views, etc. Therefore, he recommends that while creating the foundations of a new meta-science, we should work on such a state of our awareness that would lead to the formation of a common international forum of natural scientists and humanists in order to diagnose and solve more general or the most intense social problems. "The benefits of thus understood sociology of thinking are clear: it will offer an opportunity to rationally steer the intellectual life of societies. It will find ways of immunizing the masses against absolute propaganda. As a comparative science, it will counteract fanaticism, this number-one enemy of humankind." [5].

Fleck, therefore, directs our consciousness towards society. He does so not by way of mapping out our being daily participation in social life and in our dealings with those practicing different thought styles, as in ascertaining our dealings with those exercising the activities of the group of individuals whose work legitimizes significant social purposiveness. This aspect emphasizes the institutional

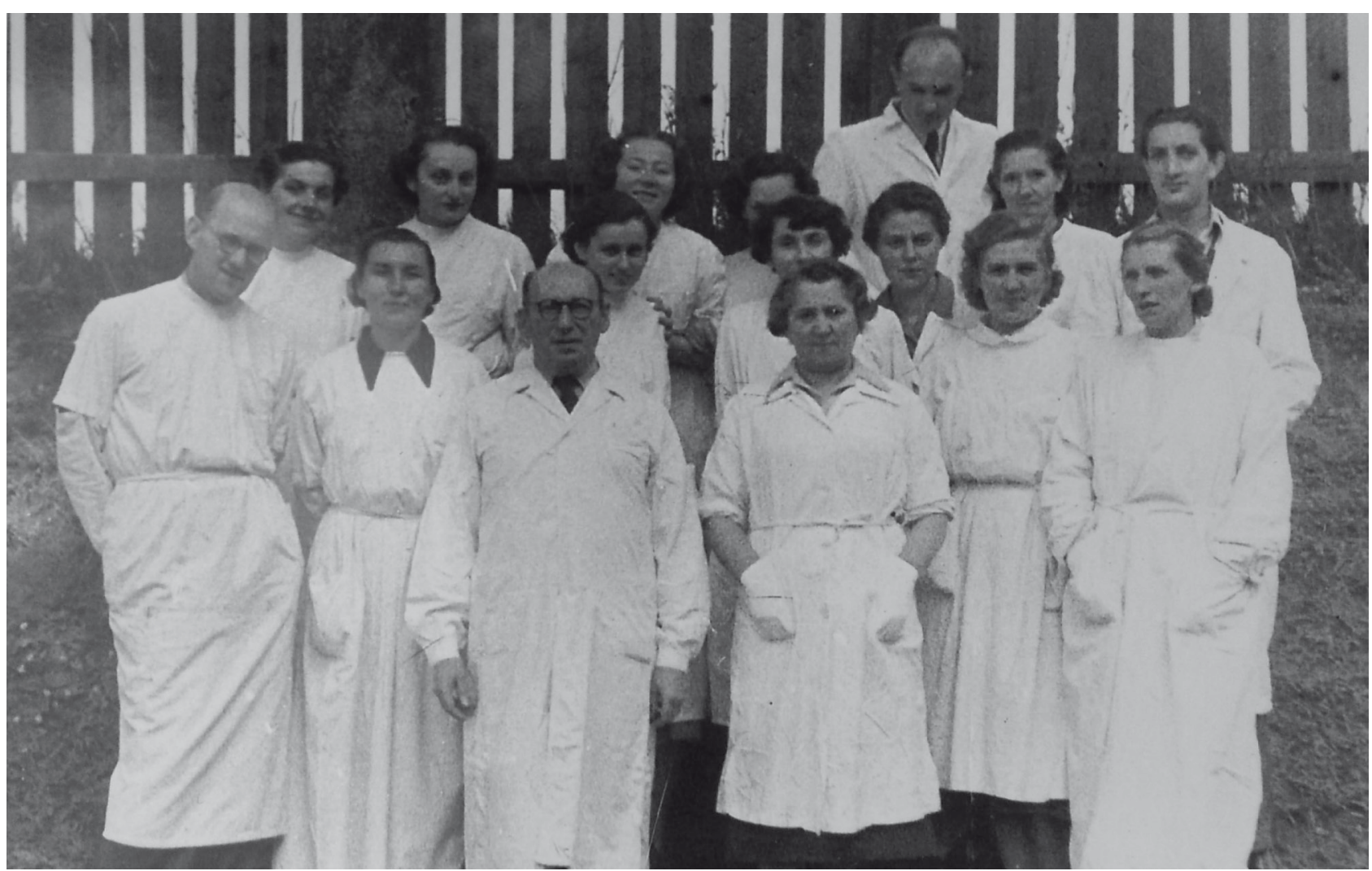

Photo 2. Ludwik Fleck with his associates. Location: Multimedia Library Teatrnn. pl [Id: oai:biblioteka.teatrnn.pl:19982]. Source: private collection of Ewa Pleszczyńska 
dimension of science in the broad sense, which (the dimension) has now to be taken more consciously into account in relation to specialist research. In that case, does this statement mean: being true to culture but not true to nature? We understand that "nature" is a cultural picture of the natural world because this is how a certain fragment of the "reality" that we study is called, while the model, by means of which it is described, is formed within a certain culture; this is ultimately the picture of a style of thinking. But this statement means something more - a call to responsibility. This clarion call is not so much in the sense of the mission of progress (although it can be said that it is proper to think that progress essentially occurs by way of science and technology) as in the sense of duty towards society, which trusts scientists with the deposit of development. Does this duty also consist in legitimizing a culture in which science arose in its theoretical, methodical and institutional dimensions? We are talking here about the European culture. It may thus be the time to reconsider its premises and foundations, if, meanwhile, it seems to be in retreat on within different domains, including that of the sphere of science.

The history of science is a significant application of canon of heuresis. Yet, one must say so with the reservation that the issue is not another paradigm of explanation, but it is about what is contained in the meaning of verstehen, what is gained by way of an understanding of a situation, and seen through a more general view-scape that is unlike scientistic reductionism. Scholars within the humanities understand that the main factors that have advanced the development of natural sciences are the utilization of the method and the heuristic rule of reductionism. The empirical method is specified by experiment and measurement (obtention of some quantity compared with the predictions of a theory) and by the approach called synthetic methodology (isolation of the studied objects under laboratory conditions to observe that which is indiscernible under natural conditions). Heuristic reductionism refers to certain applications of theory and methods of analysis, yet historically it should be analyzed in relation to the understanding brought about by way of the great number of natural sciences, and which had arose from the specification of their subjects (hence, the recent name "exact science"), and also in relation to the classic proposition that the diversity of the natural world is explained by means of "simple" rules (in philosophical language, this simplicity may mean invariability/immutability, consistence, universality). The question is, therefore, whether this methodological variant of the humanistic coefficient, on which Fleck insists, is an adequate way of departing from worldview reductionism? The meaning of this relates to the consideration of the general science of thought styles as being a set of research instruments for gaining knowledge about scientific culture, and, in this context, about what man and life is in general, and what the human social condition is, in particular. We can recognize Fleck's reasons for his insistence. These posed questions are essential within the current style of thinking about science. It is especially medicine that we can think about as a science that comes with a significant humanistic attribute; the research area here is "health", and a diagnostic case is the condition of "non-normality"; normality is studied by those who "discover" invariable rules: those who are designers of a totally rationalized, procedural society. In medicine, however, all exceptions to the rule are possible, and it is this domain of science that provides us with arguments against the designs of totalitarianism. The opposite arguments can in turn be presented here from the technological perspective; biotechnology, particularly genetic engineering, encompasses the references that most suggest themselves. In any case, Fleck provides examples of the use of historical material in the theoretical-cognitive presentation of medicine, and the picture is crucial to understanding our position as scientists within the social space. We only have to allow this theoretical-cognitive presentation to function inside regular discourse - this is also part of Fleck's postulate, while the question "what do medical specialists need this type of discourse for?" can be answered by way of its application to any academic field: for knowledge. Yet this discourse is also needed to gain position in the on-going dispute with sociologists and anthropologists, who have just forced their way into the Castalian stronghold of hard science. After all, history, in it being a cultural matrix of variables and constants, is the lowest common denominator of all sciences based on European culture.

Two papers by Fleck: On the Crisis of reality (1929) [6] and Crisis in Science. Towards a Free and More Human Science (1960) still seem to be of particular relevance. "Towards a free and more human science" [4] is a postulate that has to be read anew and re-interpreted because of what we now know. This advance in knowledge emancipates both Fleck and us from the paradox of relativism: there is something constant in thinking about science from the both the axiological and practical perspectives. This may be an application of concepts of freedom and the human dimension - the way we allow ourselves to function in society from the perspective of that practical truth which we define, after Fleck, through the attributes of dynamism, development, and creativity. Add into this recipe, the attributes of irony and contrariness (to thought coercion on the part of the collective), and it seems that this feeling of freedom, particularly in relation to science, in today's pluralist society. is most fully realized through this style.

\section{REFERENCES}

1. Biographical outline of Ludwik Fleck should be found in: Ludwik Fleck, Style myślowe i fakty. Artykuły i świadectwa. Werner S., Zittel C., Schmaltz F. (eds). Warszawa: IFiS PAN, 2007, Introduction.

2. First (German) edition of the work, under the title: Entstehung und Entwicklung einer wissenschaftlichen Tatsache, occured in 1935 (Bazylea); English edition in 1979 (London); Polish edition in 1986 (Lublin).

3. Fleck L.: Powstanie i rozwój faktu naukowego. Wprowadzenie do nauki o stylu myślowym i kolektywie myślowym, transl. by M. Tuszkiewicz. Lublin: Wydawnictwo Lubelskie, 1986, p. 64.

4. Problemy naukoznawstwa (1946) and Kryzys w naukach przyrodniczych. Ku naukom przyrodniczym wolnymi bardziej ludzkim (1960), in: Werner S., et al. (eds): Ludwik Fleck. Style myślowe i fakty. Artykuly i świadectwa. Warszawa: IFiS PAN, 2007.

5. Fleck L.: Patrzeć, widzieć, wiedzieć, in: Werner S. et al. (eds): Ludwik Fleck. Style myślowe i fakty. Artykuły i świadectwa. Warszawa: IFiS PAN, 2007, p.184.

6. Fleck L.: O kryzysie rzeczywistości (1929), in: Werner S. et al. (eds): Ludwik Fleck. Style myślowe i fakty. Artykuły i świadectwa. Warszawa: IFiS PAN, 2007. 